\title{
The Link Between Public Management and Accounting from the Point of View of Performance
}

\author{
Associate Professor Cristina Silvia NISTOR, PhD, \\ Associate Professor Cristina Alexandrina ŞTEFĂNESCU, PhD \\ "Babeş-Bolyai" University, Cluj-Napoca, Romania
}

\begin{abstract}
This study focuses on the connection between management and accounting, with accrual information as a link. Accounting information, structured on an accrual basis, manages to provide a true image of the patrimony, substantiated and transparent decisions, as a reference basis for efficient management. From of the point of view of the vast changes in the public accounting system (EPSAS), communication between accounting and tax reporting creates a unison in the presentation of financial/non-financial information, a key element in public management.

The empirical research conducted by combining the cluster analysis with the MDS technique enables us to map all EU Member States and emphasize potential connections between EU accounting systems from an accrual approach perspective, as a pillar for a performing management.

The research results reveal a widespread and strong interest in sound reporting that is able to improve transparency throughout a performing management system. These results support the EPSAS project aimed to adjust inaccuracies between accounting (IPSAS) and tax reporting (ESA 2010), and ultimately to enhance good governance and create a positive environment by facilitating transparency and comparability.
\end{abstract}

Key terms: public management, accrual, IPSAS/EPSAS, European Union, performance

JEL Classification: M48, H83, G38, C40

To cite this article: Cristina Silvia Nistor, Cristina Alexandrina Ştefănescu, The Link Between Public Management and Accounting from the Point of View of Performance, CECCAR Business Review, № 1/2021, pp. 60-72, DOI: http://dx.doi.org/10.37945/ cbr.2021.01.07

\section{Introduction}

The European Union dynamic developments reveal the need for a reformed and harmonized financial and fiscal policy, able to ensure performance management. It became more obvious especially after the bohemian period of development, disturbed by financial crises and the public system's inability to cope with them. Consequently, nowadays, the public system seems to reinvent itself, drawing attention like a "princess" metamorphosis. The importance, position and function of the public sector has been changing, becoming more complex and immersive at international level. The impetus to change is given mainly by the citizens' needs (van Ryzin et al., 2004) whose diversity and high-class requirement are obvious, as long as it funds itself through the stakeholders' contribution. The international regulatory bodies (IFAC, European Commission), whose influences are felt at the international/European level by shaping the development of the framework, are deeply involved in this process as well. 
Our study focuses on the importance of an accrual framework for public decisions. Accrual accounting as defined and introduced by the NPM reforms, provides more and accurate information about government solvency, their patrimonial goods and costs of public services (Pina and Torres, 2009). Linked with management process implications, accrual accounting is better suited to planning, financial management and decision-making (FEE, 2007). Decisions will be based on financial and non-financial information, presented in a coherent and unitary style, which is especially relevant when managers have increased autonomy to act on this improved information.

The main reason for approaching this topic is based on international reform toward accrual accounting, in local as well as in central governments, justified by the need for enhanced cost awareness and thus efficiency, the necessity to improve external accountability and oversight control, and the development of a performing management which asks for qualitative accounting information (Christiaens et al., 2010).

The key objective of this study is to reveal that an accrual approach must be an important pillar in creating a performing management in the public sector, based on transparency, efficiency and performance goals. The connection between accounting and management is based on information form and content. Grounded in strong theoretical and empirical evidence, our study is calls for a public sector evolution.

Based on a complex theoretical documentation, which combines scientific literature with official and professional documents, the empirical viewpoint contains a research methodology that successfully combines the cluster analysis with the Multidimensional Scaling (MDS) technique, also using various statistical methods to test the significance and robustness of results that come to bring added value to the public sector literature.

The originality of the study is proved both theoretically and empirically. Creating a connection between management and accounting in terms of accrual, the basis of accounting and tax reporting, respectively $-\mathrm{a}$ requirement for the new EPSAS accounting references - is an original approach meant to enrich the scientific literature. The theoretical justification and practical certification of the current circumstances at the EU level is an important reference point for the theoreticians or practitioners involved in the public sphere.

The methodological framework used for assessing the financial and fiscal accounting systems from an accrual perspective is based on a complex theoretical documentation that combines scientific literature with official and professional documents. It successfully combines the cluster analysis with the Multidimensional Scaling technique, and uses also various statistical tests to ensure the significance and robustness of results, thus adding value to the public sector literature.

The main findings of our research reveal that developing the financial/fiscal reporting systems in an accrual-based world as a basis for governmental accounting is an important milestone in a performing public sector management system.

The study addresses a wide range of users: theoreticians and academics interested in the knowledge status and research developments in public accounting standards and their impacts; practitioners with knowledge about a possible future evolution of their profession, from an assumed and known level, the national one, towards the international one; professional bodies/legislators who have a concrete and precise basis for future analysis focused on the acceptance and inclusion of the public accrual accounting references in national accounting rules.

The remainder of the paper proceeds as follows. Firstly, we provide the theoretical background for the performance approach in the public sector (section 2.1), focusing on its roots in the New Public Management and Governance paradigms and emphasizing the need for standardized reporting based on accrual principles able to improve accountability and enhance transparency through performance systems. Next, we developed a connection between the SMART objectives of a performing management and accounting on an accrual-based approach (section 2.2). Then, we develop our research questions (section 2.3) aimed to assess the EU government accounting systems from an accrual perspective as a pillar of performance. Afterward, we describe the research design and results reached (section 3 ) by applying the cluster analysis and the Multidimensional Scaling technique 
for mapping the EU countries in accordance with their fiscal and financial accounting systems. Finally, we provide our conclusions revealing the development of high-performing public entities with added value to society, given that the framework for this process, namely the interdependency between management and accounting is based on accrual information. These approaches are accepted at the EU level by most public sector entities, public policies, public standard setters and so on. The adoption of the accrual concept is recognized as a catalyst for other management reforms in the public sector (Blondal, 2004).

\section{Theoretical background}

\subsection{New concepts regarding the performance framework in the public sector approach}

During the last decades, the public sector has been marked by the "big paradigm shift" (Klijn, 2012) between New Public Management (hereafter NPM) and New Public Governance (hereafter NPG), both focused on providing more comparable and relevant information for the decision-making process within the public sector. In this context, concepts like performance, transparency, accountability and efficiency became common in the language of public institutions (Nistor et al., 2016). Moreover, improving accountability and enhancing transparency through performance systems was perceived as fundamental to both public management reforms (Almquist et al., 2013). This view rests on their roots, NPM being connected to individual organizations using comprehensive concepts of accrual accounting and financial reporting, while NPG has a multi-organizational focus with a particular interest in "Whole-of-Government Accounting" (WGA), accountability and value for money (Caperchione et al., 2017).

Scientific literature reveals that performance measurement and reporting, as tools adopted to support both NPM and NPG (Arnaboldi et al., 2015; Pollitt, 2013), have been deeply researched over time and comprehensively reviewed (Cuganesan et al., 2014; van Helden et al., 2008) in order to highlight their relevance and importance. According to these pieces of evidence, performance measurement and reporting were born as a necessary response to public pressure for accountability, public entities being continuously encouraged to disclose information and to be responsible for their actions. This performance-based accountability tradition evolved, along with the goals of the NPG movement, towards performance transparency, as well (Bolivar and Galera, 2016; Bolivar et al., 2013).

However, there still is no consensus on the real usefulness of performance information (Manes-Rossi and Aversano, 2015). In addition to that, shreds of evidence emphasize considerable differences between performance measurement and reporting systems worldwide caused by institutional, cultural and historical issues particular to each country (Benito et al., 2007). Moreover, both literature and practical evidence underlined the insufficiency of strictly financial information for accountability purposes and the increasing necessity of non-financial information, especially performance-related information.

Consequently, a performance measurement system has been acclaimed (Brusca and Montesinos, 2016) as a tool for producing information to quantify the efficiency and effectiveness of actions, proving useful both in providing information for decision-making purposes (internal use) and in disseminating information on local government performance for accountability purposes (external use). After intensive debates among jurisdictions and regulatory bodies, they came up with the idea of including performance reporting into the annual reports of governmental entities. In this regard, the IPSASB (2015) recently issued Recommended Practice Guideline 3: Reporting Service Performance Information, which states that service performance information that helps users assess how efficiently and effectively public sector entities are using resources in order to provide services and achieve their objectives, is an important part of general-purpose financial reports.

Anyway, in the new area of open government initiatives, new challenges to government will arise in important core values such as accountability, efficiency and transparency (Ingrams, 2018). 
In this context, researchers and regulatory bodies alike have been actively involved over time throughout supportive implications into governments' actions meant to enhance performance in the public sector at both micro and macro level through their financial accounting and fiscal systems. Thus, all reforms undergone overtime were grounded on high-quality and relevant information as a prerequisite for enhancing transparency and accountability of the EU countries' financial and fiscal policy. However, the pluralistic mosaic of public sector public accounting in Europe (Manes-Rossi et al., 2016) and the long, twisted path towards harmonization (Brusca et al., 2015; Christiaens et al., 2015) creates barriers in getting accurate, reliable and comparable accounting and fiscal information. Nonetheless, accrual accounting has been recognized since long ago as the accounting method which introduced the value-for-money notion in the public sector, supported by techniques of costing, budgeting and performance management (Jackson and Lapsley, 2003). It lays the foundation for better governmental performance management, since it is the basis for better accountability, fostering a greater level of credibility throughout high-quality information content for financing decisions (Ferry et al., 2018).

Embracing this viewpoint, various international organizations (such as the International Public Sector Accounting Standards Board (IPSASB), the Organization for Economic Co-operation and Development (OECD), the European Commission and the European Council) came to support this opinion (Heald and Hodges, 2015) claiming that transparent and reliable disclosure of both financial and fiscal positions becomes necessary due to the strongly-connected economic and political approaches of the EU countries. Thus, the European Commission recognizes that a standardized reporting based on accrual principles is able to provide the most complete and only reliable image of a government's performance, thus increasing accountability, openness and transparency (European Commission, 2013). Therefore, the accrual concept became a benchmark for both financial and fiscal public policy (Nistor and Ștefănescu, 2018), able to support a sound performance management system.

\subsection{SMART objectives and goals through accrual information}

Modernizing public sector accounting rests on several pillars, the financial and fiscal reporting being two of the most important ones, with implications for the efficient use of public resources (Guarini and Pattaro, 2016). At European Union level, the access to accurate and reliable information useful for the decision-making process in public finances management (Chan et al., 2006) is a testament of public accountability, enhancing performance (Caba Perez and Lopez-Hernandez, 2009).

An efficient management without specific, clear, reasonable goals and objectives is incomplete. You must know the real goals as a distinct purpose that is to be anticipated for your public entities' development, and on the other hand, the objectives which determine the steps that will lead to the full completion of the project goals.

Taking into account this approach, in our opinion and according to Poister (2008), the most traditional approach to performance management is management-by-objectives. It is based on the setting of objectives developed according to the specific - measurable - achievable - relevant - time-bound (SMART) concept, participative decision-making and objective feedback (Rodgers and Hunter, 1992; Poister, 2003). In the public sector, perhaps more than in other areas, you need to take action towards your goals with strong, correct and well-founded steps, based on legislative, economic, political and financially correct information. Public entities operate in a political environment dealing not only with efficiency and effectiveness issues, but also with justice, equity, and accountability (Carroll, 2004). A sound performing management system needs to be governed by an ongoing monitoring and reporting of progress towards pre-established goals. The later will not magically occur even if you come up with a fantastic SMART goal. If you do not act on them with measurable, agreed, realistic information, the whole process will be a fiasco. 
In this complex process, the accrual concept comes to offer an improved quality to financial and public policy, by creating an efficient and transparent reporting, with implications for public performance (Tickell, 2010). We consider that to be an accurate definition of a public entity's performance and management is in terms of economy, efficiency and effectiveness. The aim of these concepts in the public sector was to make the objectives, performance, and (used) resources clear; to integrate financial and nonfinancial information; to integrate the policy and budget cycles; and to improve quality, accessibility, and information content of the management information (de Waal and Kerklaan, 2004). The international literature supports the benefits of applying accrual accounting by considering a transparent, clear and relevant vision of performance in public institutions (Newberry, 2014; Brusca and Montesinos, 2016) increasing public accountability (Likierman,2003; Magalhães et al., 2013), improving information disclosure (Yamamoto, 2004) and the ability to faithfully represent financial information (Hodges and Mellett, 2003; Pallot, 2001). Anyway, counter views state that the impact of accrual numbers on the fiscal stance of a country does not seem very relevant (Giosi et al., 2015), due to the absence of consistency with the budgetary practices (Jones et al., 2014). The existing budgeting system, which mainly focused on resource application, needed to be replaced with a budgeting system with an explicit link to the objectives to be achieved, the required resources to accomplish them, and the expected and realized results (de Waal and Kerklaan, 2004).

In this context, our study comes with a new approach, proving the utility of the accrual concept (see Table 1) through two aspects: designing and substantiating objectives and goals (SMART) as well as reporting and evaluating their achievement. Moreover, the accrual concept becomes the link between national reforms (Abushamsieh et al., 2013) and the international bodies' vision, who unanimously accept the complexity of theory at least regarding sound technical expertise and the great amount of judgment required (Mhaka, 2014).

Table 1. Connection between SMART objectives

and the accrual-based accounting approach

\begin{tabular}{ccl}
\hline $\begin{array}{c}\text { SMART } \\
\text { concept }\end{array}$ & \multicolumn{1}{c}{$\begin{array}{c}\text { SMART } \\
\text { meaning* }\end{array}$} & \multicolumn{1}{c}{ Accrual connection $^{* *}$} \\
\hline Specific & $\begin{array}{l}\text { Target a specific area } \\
\text { for improvement. }\end{array}$ & $\begin{array}{l}\text { When a business wants to examine its actual performance during } \\
\text { a specific activity/period of time the accrual method of } \\
\text { accounting is a useful tool. It is based on the matching principle, } \\
\text { where revenues are recorded for the period when goods and } \\
\text { services are delivered, and expenses are recorded when goods } \\
\text { and services are purchased (thereby matching revenues earned } \\
\text { against expenses incurred during the same accounting period). }\end{array}$ \\
\hline Measurable & $\begin{array}{l}\text { Quantify or at least } \\
\text { suggest an indicator } \\
\text { of progress. }\end{array}$ & $\begin{array}{l}\text { The use of accrual accounts has greatly increased the amount } \\
\text { of information on accounting statements. Accrual accounting } \\
\text { measures the performance and position of a public entity by } \\
\text { recognizing economic events regardless of when cash transactions } \\
\text { occur. The accrual principle is an accounting concept that requires } \\
\text { accounting transactions to be recorded in the time period in which } \\
\text { they occur, regardless of the time period when the actual cash } \\
\text { flows for the transaction are received. }\end{array}$ \\
& $\begin{array}{l}\text { Financial and non-financial information is capable of making } \\
\text { a difference in achieving the objectives of financial reporting. }\end{array}$ \\
\hline Achievable & $\begin{array}{l}\text { The objective must } \\
\text { be attainable, given } \\
\text { the amount of time } \\
\text { and resources } \\
\text { available. }\end{array}$ & \begin{tabular}{l} 
\\
\hline
\end{tabular}
\end{tabular}




\begin{tabular}{cll}
\hline $\begin{array}{c}\text { SMART } \\
\text { concept }\end{array}$ & \multicolumn{1}{c}{$\begin{array}{c}\text { SMART } \\
\text { meaning* }\end{array}$} & \multicolumn{1}{c}{ Accrual connection $^{* *}$} \\
\hline Realistic & $\begin{array}{l}\text { State what results } \\
\text { can realistically } \\
\text { be achieved, given } \\
\text { available resources. }\end{array}$ & $\begin{array}{l}\text { Faithful representation }- \text { is attained when the depiction of the } \\
\text { phenomenon is complete, neutral, and free from material error. }\end{array}$ \\
\hline Timely & $\begin{array}{l}\text { Specify when } \\
\text { the result(s) can } \\
\text { be achieved. }\end{array}$ & $\begin{array}{l}\text { Timeliness - having information available for users before it loses } \\
\text { its capacity to be useful for accountability and decision-making } \\
\text { purposes. }\end{array}$ \\
\hline
\end{tabular}

* Based on scientific literature review (Rodgers and Hunter, 1992; van Helden et al., 2008; Magalhães et al., 2013; Nistor et al., 2016).

** Based on IPSAS references online at https://www.ipsasb.org (accrual IPSASs issued as at December 31, 2018).

Provided that the objectives are SMART - specific, measurable, achievable, relevant and timely, and that their achievement is monitored by performance concepts, this is likely to provide a clear and suitable reference basis for assessing effectiveness (Daujotaitè and Mačerinskienè, 2008), transparency and performance management in the public sector.

"Financial management, whether at the macro level (general government) or the micro level (the government entity), should be based on the principle of accruals accounting", thus "superiority of accruals principle whether for macro or micro fiscal monitoring is indisputable" (European Commission, 2013). Also, regarding financial reporting standardization, the European Commission mentions that "accruals accounting is the only generally accepted information system that provides a complete and reliable picture of the financial and economic position and performance of a government" (European Commission, 2013).

\subsection{Research question development}

The motivation of this study is supported by the above-mentioned scientific opinions and regulatory arguments which reveal that financial and fiscal policies are based on the two forms of governmental accounting jointly-connected by the accrual concept.

In this broad context of developments in the financial and budgeting/statistical accounting, the primary objective of this study is to prove that the accrual basis is the key-issue of improving financial and fiscal reporting in the EU. Thus, the accrual level is appraised as a reference basis from a double perspective: accounting and fiscal, also approached as a pillar of performance in the public sector.

Consequently, the following research question of this study has arisen: (RQ) What is the view of EU accounting systems from the accrual approach perspective as a pillar of performance?

In conclusion, New Public paradigms and accrual basis accounting are the best way to improve public sector management, to increase the transparency and raise the efficiency, since managers' decisions are mainly based on accounting and fiscal reporting.

\section{Research design and results}

\subsection{Methodology framework}

Aiming to fulfilling our research objective, we performed an exploratory data analysis (EDA) among EU Member States (we have included the UK in the study for two reasons: on the one hand, it is extremely relevant for the accrual system, the basic reference element for our study and, on the other hand, the studies and official reports on the EU are still based on the UK's reporting, Brexit having occurred relatively soon) to review and visually represent the leading features of both fiscal and accounting systems in the public sector, thus pinpointing and matching the general outlines developed. 
Therefore, for emphasizing how the EU accounting system views the accrual approach as a pillar of performance (RQ) we proceeded to assess both fiscal and financial accounting systems taking into account the extent to which the accrual basis was adopted.

To achieve this goal, we assigned values ranging from " 1 " to " 4 " to the accounting system of each country (Acc_Sys), and from "1" to " 3 " for its fiscal accounting and reporting basis (Fisc_Sys) (see Table 2).

Table 2. Variables considered for the empirical analysis

\begin{tabular}{ccccc}
\hline \multirow{2}{*}{ Variables } & \multicolumn{4}{c}{ Values assigned } \\
\cline { 2 - 5 } & "1" & "2" & "3" & "4" \\
\hline Acc_Sys & cash & mixed & modified accrual & accrual \\
Fisc_Sys** & cash & mixed & accrual & NA \\
\hline
\end{tabular}

* The accounting system (European Commission, 2015; PwC, 2014; Bellanca et al., 2015).

${ }^{* *}$ The reporting basis of the fiscal data published by the EU Member States on the European Commission's initiative of assessing the compliance with the Council Directive 2011/85/EU, Article 3(2) related to fiscal data (European Commission, 2015).

For accomplishing our research objective, we performed a hierarchical cluster analysis, followed by the Multidimensional Scaling technique (MDS) aiming to underline potential connections between the fiscal and financial systems able to support the need for accrual harmonization as a pillar for performance in public sector.

Subsequently, in order to ascertain the results reached after performing the cluster analysis on the EU countries' sample, we performed various checks, namely the homogeneity test (Levene) that confirmed the five cluster solutions reached, respectively the robustness tests (Brown-Forsythe and Welch) that increased the results' reliability.

Furthermore, in order to complete the results of the cluster analysis, we applied the Multidimensional Scaling technique to reveal our countries' sample into two dimensions: fiscal vs. financial accounting system. To increase the reliability of the mapping solution, we applied the Stress test (Kruskal's type I) whose values confirm an excellent match for the MDS results reached, thus answering our research question.

In conclusion, our study adds value to the scientific research on the public sector even though it follows similar methodology (Nistor and Ștefănescu, 2016; Nistor and Ștefănescu, 2018; Pina et al., 2009) to prior studies through due to a more extensive sample comprising all $28 \mathrm{EU}$ Member States and a wider research topic focusing on both the financial and fiscal accounting systems. Moreover, it increases the trustworthiness of our findings through more reliable results certified by various statistical tests.

In conclusion, our comprehensive research comes to support a harmonized reporting useful for budget surveillance, fiscal monitoring or sound decision-making. Moreover, it encourages comparability, reliability and transparency in the public sector, thus enhancing accountability and performance by having the accrual basis as a cornerstone.

\subsection{Data and results}

Aiming to provide a comprehensive portrait of the European fiscal and financial accounting environment, we focused on emphasizing the role of the accrual approach as a pillar of performance in the EU public accounting systems (RQ).

Thus, we launched our empirical research by using the hierarchical cluster analysis in order to organize our sample into homogenous groups, as different as possible, called clusters, by including into the same cluster only the most similar EU countries sharing common characteristics. 


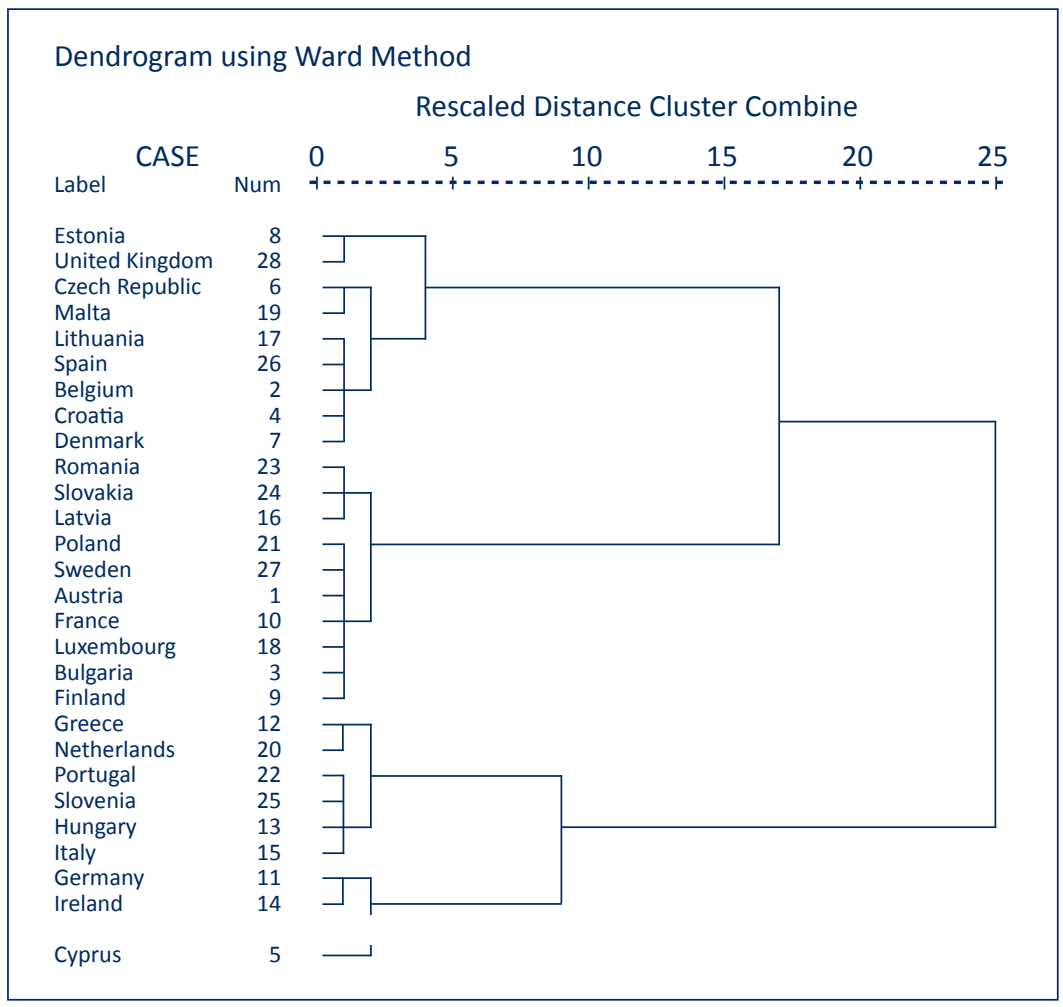

Figure 1. Dendrogram of the cases - fiscal vs. financial accounting system

According to the dendrogram reached, the vertical axis helped us find the most suitable rate of clustering by considering the distance between individual clusters showed by the horizontal axis. Thus, the dendrogram reveals five significant clusters in the case classification process (encoded group " $A$ " to " $E$ "). These clusters encompass all $28 \mathrm{EU}$ countries' samples according to the status of their fiscal and financial accounting systems judged from an accrual perspective (see Figure 1).

In the following step of the analysis, the optimal five-cluster solution reached was subject to various significance tests carried out to increase the reliability of our results (see Table 3).

Table 3. Significance test results for cluster analysis

\begin{tabular}{|c|c|c|c|c|c|c|c|c|c|}
\hline \multicolumn{5}{|c|}{ Test of Homogeneity of Variances } & \multicolumn{5}{|c|}{ Robust Tests of Equality of Means } \\
\hline & Statistic & df1 & df2 & Sig. & & Statistic ${ }^{a}$ & df1 & $\mathrm{df2}$ & Sig. \\
\hline Levene $^{*}$ & 41.071 & 4 & 23 & .000 & Welch $^{*}$ & 43.978 & 4 & 6.900 & .000 \\
\hline Levene $^{* *}$ & 29.731 & 3 & 24 & .061 & Brown Forsythe ${ }^{*}$ & 37.554 & 4 & 7.330 & .000 \\
\hline
\end{tabular}

Thus, the homogeneity test applied justifies the number of clusters (the Levene's test significance), while the robustness tests (the Brown-Forsythe and Welch versions of the F-ratio) increase the trustworthiness of the solution, due to their high significance.

To complete the results of our analysis, we mapped the sample of countries into a chart (see Figure 2) by applying the Multidimensional Scaling technique. Thus, we provided a portrait with two dimensions: financial (dimension 1) vs. fiscal (dimension 2) accounting systems, in which the interconnected EU countries were placed. 


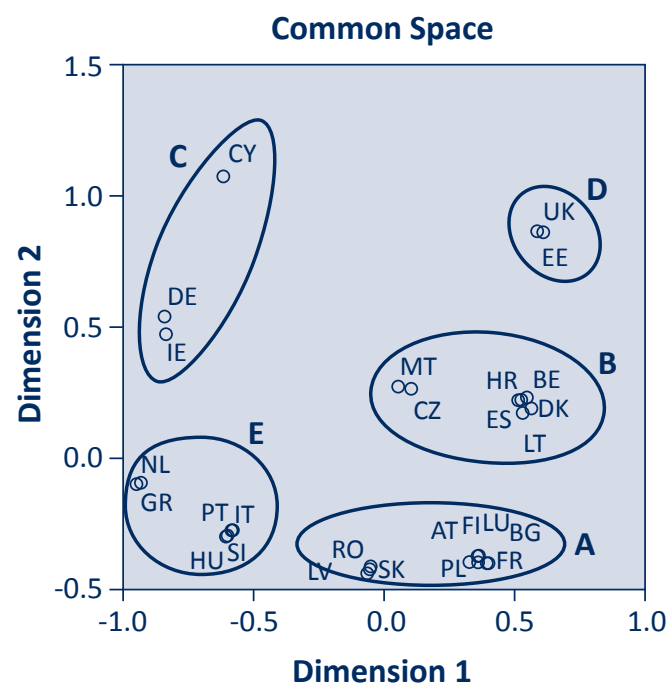

where:
Groups' legend:

Austria (AT), Bulgaria (BG), Finland (FI), France (FR),

"A" Latvia (LV), Luxembourg (LU), Poland (PL), Romania (RO), Slovakia (SK), Sweden (SE)

Belgium (BE), Croatia (HR), Czech Republic (CZ),

"B" Denmark (DK), Lithuania (LT), Malta (MT), Spain (ES)

"C" Cyprus (CY), Germany (DE), Ireland (IE)

“D” Estonia (EE), United Kingdom (UK)

"E" Greece (GR), Hungary (HU), Italy (IT),

Netherlands (NL), Portugal (PT), Slovenia (SI)

Dimension 1 - Financial accounting system Dimension 2 - Fiscal accounting system

Figure 2. Mapping EU Member States into groups according to the status of their fiscal and financial accounting systems taking into account the accrual basis adoption

To increase the reliability of the mapping, we used the Stress test (Kruskal's type I), whose value (0.0547) certifies a good match of the sample placements on the MDS map.

Therefore, the mapping of the EU Member States into groups reveals the status of both fiscal and financial accounting systems from the accrual approach perspective and provides evidence meant to support its standing as a pillar of performance, thus answering our first research question (RQ).

As follows, we will put emphasis on each group's essential features, trying to reveal how the adoption of a full accrual framework in the public sector varies across countries according to the latest trends in accounting. Our mapping shows that the accrual basis seems to be adopted differently in national fiscal systems as opposed to the accounting ones. If only a few countries, situated at the top of the map, provide full accrual fiscal reporting (e.g. Estonia and the UK from Group " $D$ " and Cyprus from Group " $C$ "), the situation is quite encouraging from the accounting perspective. Thus, in the wave of NPM reform, the vast majority of countries encompassed by Group " $\mathrm{A}$ ", "B" and " $\mathrm{D}$ " have widely adopted an accrual basis within their accounting systems (including its intermediate form of modified-accruals). These countries actually used it as a tool to gain wider accountability and to demonstrate the a considerate, efficient and effective usage of public resources (Barton, 2011; IFAC, 2014). In this context, there seems to be a wide opening towards the harmonization of the accounting systems of these groups. They certainly understand the demand for homogeneous forms of accounting to support fiscal transparency across the EU Member States (Miller and Power, 2013) and their valuable impacts on public sector performance management (Steger, 2010), thus being in line with the Post-NPM paradigm. The leaders of convergence between the two accounting systems - fiscal and financial - are the UK and Estonia (Group “D”), the early adopters of accrual accounting and budgeting (Hyndman et al., 2014). They have already acknowledged the indisputable benefits of harmonized and good quality data for fiscal transparency (Heald and Hodges, 2015).

A proper positioning on the map can be noticed in the case of Group " $\mathrm{B}$ ", which is one step away from convergence since most countries within this group use mixed budgets and at least modified-accrual principles. Some of them (e.g. Spain, Malta and Croatia) have even agreed that reporting on an accrual basis is more useful because cash-accrual adjustments become less significant, with a lower impact on the country's deficit/surplus (Jesus and Jorge, 2015). 
However, there are countries situated on the opposite side of the spectrum (Group "E" and partially Group " $C^{\prime}$ ), still using the cash basis in their fiscal system, while the financial one is either in cash or accrual. Such underpinnings are potentially crucial for the future of public sector accounting internationally (Ellwood and Newberry, 2016) because they might create barriers for accounting systems harmonization. One possible reason is that such countries do not yet acknowledge the importance of integrating the cash and accrual accounting and budgeting systems into one comprehensive financial management information and reporting system, which would be useful for governments (Barton, 2011). They appreciate the importance of the cash budgeting process (e.g. Germany), thus criticizing the use of accrual accounting due to its inconsistency with budgeting practices (Jones et al., 2014). Consequently, they are still unaware of whether accruals are better than cash-based accounting and budgeting (Becker et al., 2013). Moreover, pieces of evidence coming from countries under severe financial strain and deep-rooted bureaucracy (e.g. Greece) reveal that their reform was only meant to comply with demand, rather than to improve public financial management (Cohen and Karatzimas, 2016). In this context, countries included in Group " $E$ " will encounter the greatest difficulties in aligning to the future reforms aimed to launch a unique framework for budgeting and accounting purposes meant to enhance future performance in the public sector.

Despite all this, most European accounting systems (Groups " $A$ " to " $D$ ") are leading through the accrualbasis, which creates prerequisites for harmonization with their fiscal systems, too. This assertion is supported by our empirical results which reveal an appropriate location of the largest part of the sample countries at the junction point between modified accruals leading to full accrual accounting and fiscal systems mostly mixed-based.

In conclusion, this view of the EU accounting systems from the accrual approach perspective as a pillar of performance provides the virtual answer to the aim of our first research question (RQ1). In fact, it promotes the harmonization between fiscal and financial accounting systems, thus creating the premises for reliable, comparable and transparent reporting and performance-oriented systems, supported by the NPG paradigm.

\section{$\rightarrow$ Conclusions}

The development trends in the public sector were deeply marked overtime by the New Public Management paradigm, followed especially in the recent years by the good governance concept, the cornerstone for efficient and effective organizational performance. In this context, enhancing governmental performance required not only improvements in public accountability of governments, but also greater transparency in order to increase citizens' trust through performance management systems that provide more comparable, relevant and useful information for decision-making within the public sector.

Evidence reveals that these requirements have continuously challenged public sector accounting and it still is a subject that requires deep harmonization due to the inconsistencies between the financial and fiscal systems. These are mainly due to the opposite opinions on governmental reporting, namely informing decisionmakers and promoting accountability (IPSASB, 2014) and providing information for statistical reporting able to support ESA 2010 and fiscal surveillance (European Commission, 2013). In this heterogeneous and twisted background, there is an undeniable need for promoting comparable and high-quality reporting practices able to increase transparency and accountability, thus supporting performance management systems.

Our paper comes to enrich the research literature through a complex study aimed to provide a comprehensive picture of the EU public sector accounting system focusing on promoting the accrual concept in both financial and fiscal reporting systems, as a base for the future dynamics of EPSAS development.

The novelty of the research is ensured by approaching the relationship between fiscal and financial accounting systems through the accrual concept perspective as a source of information able to support a sound performing management system. Moreover, we added value to the scientific literature, given that we assessed and depicted this connection within all EU Member States.

Thus, we intended to emphasize the view of the EU accounting systems from the accrual approach perspective $(R Q)$, aiming to promote a harmonized accrual-based system for both financial and fiscal accounting with valuable impacts on public sector performance management, based on wider accountability and deeper information accuracy. 
Our results support the demand for a unique and comprehensive framework for budgeting and financial reporting purposes since the EU fiscal image has been distorted by unreliable information coming from different accounting systems: the financial one mainly focused on accruals and the fiscal one mostly relying on cash principles. The view of the EU accounting systems provided by our mapping confirms the latest trends in their development marked by the New Public Management reform consisting of a wide and strong interest in sound reporting able to increase the quality and comparability of information ensured through accrual principles. Professional judgment along with scientific evidence in public sector literature came to support, over time, the harmonization project across EU Member States by promoting uniform standards for both financial and fiscal accounting. Thus, these standards either focused on micro-level (IPSAS) or macro-level (ESA 2010) were designed to enhance financial performance comparability across Europe.

In this context, the mapping of the EU reporting systems provided by our empirical analysis justifies the need for harmonization between fiscal and financial facets of public accounting, which can be ensured throughout an accrual approach.

In conclusion, management and accounting are strongly inter-connected through the accrual information, an important pillar in creating a performing management system in the public sector, based on reliable, comparable and transparent reporting.

\section{References}

1. Abushamsieh, K., López-Hernández, A.M., Ortiz-Rodríguez, D. (2013), Administrative Reforms to Governmental Financial Information Systems in GCC Countries: The Case of Qatar, Middle Eastern Studies, Vol. 49, No. 5, pp. 790-804.

2. Almquist, R., Grossi, G., van Helden, G.J., Reichard, C. (2013), Public Sector Governance and Accountability, Critical Perspectives on Accounting, Vol. 24, No. 7-8, pp. 479-487.

3. Arnaboldi, M., Lapsley, I., Steccolini, I. (2015), Performance Management in the Public Sector: The Ultimate Challenge, Financial Accountability and Management, Vol. 31, No. 1, pp. 1-22.

4. Barton, A. (2011), Why Governments Should Use the Government Finance Statistics Accounting, Abacus, Vol. 47, No. 4, pp. 411-445.

5. Becker, S.D., Jagalla, T., Skærbæk, P. (2013), The Translation of Accrual Accounting and Budgeting and the Reconfiguration of Public Sector Accountants' Identities, Critical Perspectives on Accounting, Vol. 1, No. 1, pp. 324-338.

6. Bellanca, S., Cultrera, L., Vermeylen, G. (2015), Analysis of Public Accounting Systems in the European Union, Research in World Economy, Vol. 6, No. 3, pp. 23-35.

7. Benito, B., Brusca, I., Montesinos, V. (2007), The Harmonization of Government Financial Information Systems: The Role of IPSASs, International Review of Administrative Sciences, Vol. 73, No. 2, pp. 293-317.

8. Blondal, J.R. (2004), Issues in Accrual Budgeting, OECD Journal on Budgeting, Vol. 4, No. 1, pp. 108-119.

9. Bolivar, R.M.P., Caba Perez, M.C., Lopez-Hernandez, A.M. (2013), Online Budget Transparency in OECD Member Countries and Administrative Culture, Administration and Society, Vol. 47, No. 8, pp. 943-982.

10. Bolivar, R.M.P., Galera, A.N. (2016), The Effect of Changes in Public Sector Accounting Policies on Administrative Reforms Addressed to Citizens, Administration and Society, Vol. 48, No. 1, pp. 31-72.

11. Brusca, I., Caperchione, E., Cohen, S., Manes-Rossi, F. (2015), Public Sector Accounting and Auditing in Europe: The Challenge of Harmonization, Palgrave Macmillan, UK.

12. Brusca, I., Montesinos, V. (2016), Implementing Performance Reporting in Local Government: A Cross-Countries Comparison, Public Performance and Management Review, Vol. 39, No. 3, pp. 506-534.

13. Caba Perez, C., Lopez-Hernandez, A.M. (2009), Governmental Financial Transparency in MERCOSUR Member Countries, International Review of Administrative Sciences, Vol. 75, No. 1, pp. 169-181.

14. Caperchione, E., Demirag, I., Grossi, G. (2017), Public Sector Reforms and Public Private Partnerships: Overview and Research Agenda, Accounting Forum, Vol. 41, No. 1, pp. 1-7.

15. Carroll, K.A. (2004), Property Rights and Managerial Decisions in For-Profit, Non-Profit and Public Organizations, Palgrave Macmillan, Gordonville, USA. 
16. Chan, K.C., Chen, C.R., Cheng, L.T. (2006), A Ranking of Accounting Research Output in the European Region, Accounting Business Research, Vol. 36, No. 1, pp. 3-17.

17. Christiaens, J., Reyniers, B., Rollé, C. (2010), Impact of IPSAS on Reforming Governmental Financial Information Systems: A Comparative Study, International Review of Administrative Sciences, Vol. 76, No. 3, pp. $537-554$.

18. Christiaens, J., Vanhee, C., Manes-Rossi, F., Aversano, N., van Cauwenberge, P. (2015), The Effect of IPSAS on Reforming Governmental Financial Reporting: An International Comparison, International Review of Administrative Sciences, Vol. 81, No. 1, pp. 158-177.

19. Cohen, S., Karatzimas, S. (2016), Modernizing Government Accounting Standards in Greece: A Case of "Garbage Can" Decision-Making, Public Money and Management, Vol. 36, No. 3, pp. 173-180.

20. Cuganesan, S., Guthrie, J., Vranic, V. (2014), The Riskiness of Public Sector Performance Management: A Review and Research Agenda, Financial Accountability and Management, Vol. 30, No. 3, pp. 279-302.

21. Daujotaitè, D., Mačerinskienè, I. (2008), Development of Performance Audit in Public Sector, Finance Engineering, pp. 177-185.

22. De Waal, A., Kerklaan, L. (2004), De resultaatgerichte overheid: Op weg naar de prestatiegedreven overheidsorganisatie, Sdu Uitgevers, Den Haag.

23. Ellwood, S., Newberry, S. (2016), New Development: The Conceptual Underpinnings of International Public Sector Accounting, Public Money and Management, Vol. 36, No. 3, pp. 231-234.

24. Ferry, L., Zakaria, Z., Zakaria, Z., Slack, R. (2018), Framing Public Governance in Malaysia: Rhetorical Appeals Through Accrual Accounting, Accounting Forum, Vol. 42, No. 2, pp. 170-183.

25. Giosi, A., Brunelli, S., Caiffa, M. (2015), Do Accrual Numbers Really Affect the Financial Market? An Empirical Analysis of ESA Accounts Across the EU, International Journal of Public Administration, Vol. 38, No. 4, pp. $297-310$.

26. Guarini, E., Pattaro, A.F. (2016), Deficit Control and Fiscal Austerity in the EU: Time to Consider the Local Impact, International Journal of Public Sector Performance Management, Vol. 2, No. 4, pp. 348-369.

27. Heald, D., Hodges, R. (2015), Will "Austerity" Be a Critical Juncture in European Public Sector Financial Reporting?, Accounting, Auditing and Accountability Journal, Vol. 28, No. 6, pp. 993-1015.

28. Hodges, R., Mellett, H. (2003), Reporting Public Sector Financial Results, Public Management Review, Vol. 5, No. 1, pp. 99-113.

29. Hyndman, N., Liguori, M., Meyer, R.E., Polzer, T., Rota, S., Seiwald, J. (2014), The Translation and Sedimentation of Accounting Reforms. A Comparison of the UK, Austrian and Italian Experiences, Critical Perspectives on Accounting, Vol. 25, pp. 388-408.

30. Ingrams, A. (2018), Transparency for Results: Testing a Model of Performance Management in Open Government Initiatives, International Journal of Public Administration, Vol. 41, No. 13, pp. 1033-1046.

31. Jackson, A., Lapsley, I. (2003), The Diffusion of Accounting Practices in the New "Managerial" Public Sector, International Journal of Public Sector Management, Vol. 16, No. 5, pp. 359-372.

32. Jesus, M.A., Jorge, S. (2015), Government Budgetary Reporting Systems in the European Union: Is the Accounting Basis Relevant for the Deficit Reliability?, International Review of Administrative Sciences, Vol. 81, No. 1, pp. $110-133$.

33. Jones, R., Lande, E., Lüder, K., Portal, M. (2014), Comparison of Budgeting and Accounting Reforms in the National Governments of France, Germany, the UK and the US, Financial Accountability and Management, Vol. 29, No. 4, pp. 419-441.

34. Klijn, E.H. (2012), New Public Management and Governance: A Comparison of Two Paradigms to Deal with Modern Complex Problems, in D. Levi-Faur (Editor), The Handbook of Governance, Oxford University Press, pp. 201-214.

35. Likierman, A. (2003), Planning and Controlling UK Public Expenditure on a Resource Basis, Public Money and Management Review, Vol. 23, No. 1, pp. 45-50.

36. Magalhães, A., Veiga, A., Ribeiro, F.M., Sousa, S., Santiago, R. (2013), Creating a Common Grammar for European Higher Education Governance, Higher Education, Vol. 65, No. 1, pp. 95-112.

37. Manes-Rossi, F., Aversano, N. (2015), Advancing Performance Measurement Italian Local Government vis-à-vis the IPSASB Project, International Journal of Productivity and Performance Management, Vol. 64, No. 1, pp. 76-93.

38. Manes-Rossi, F., Cohen, S., Caperchione, E. (2016), Harmonizing Public Sector Accounting in Europe: Thinking Out of the Box, Public Money and Management Review, Vol. 36, No. 3, pp. 189-196.

39. Mhaka, C. (2014), IPSAS, A Guaranteed Way of Quality Government Financial Reporting? A Comparative Analysis of the Existing Cash Accounting and IPSAS Based Accounting Reporting, International Journal of Financial Economics, Vol. 3, No. 3, pp. 134-141. 
40. Miller, P., Power, M. (2013), Accounting, Organizing and Economizing: Connecting Accounting Research and Organization Theory, The Academy of Management Annals, Vol. 7, No. 1, pp. 555-603.

41. Newberry, S. (2014), The Use of Accrual Accounting in New Zealand's Central Government: Second Thoughts, Accounting, Economics and Law, Vol. 4, No. 3, pp. 283-297.

42. Nistor, C.S., Ştefănescu, C.A. (2016), The Managerial Decisions for the European Union Under the Siege of Changes in the Public Sector Accounting, African Journal of Accounting, Auditing and Finance, Vol. 5, No. 3, pp. $207-230$.

43. Nistor, C.S., Ştefănescu, C.A. (2018), Public Accounting Reporting, Under an Achievable Metamorphosis?, Current Science, Vol. 114, No. 10, pp. 2131-2137.

44. Nistor, C.S., Ştefănescu, C.A., Sintejudeanu, M.A. (2016), Performance Management and Balanced Scorecard A Link for Public Sector, The Journal of Accounting and Management, Vol. 6, No. 3, pp. 5-25.

45. Pallot, J. (2001), A Decade in Review: New Zealand's Experience with Resource Accounting and Budgeting, Financial Accountability and Management, Vol. 17, No. 4, pp. 383-400.

46. Pina, V., Torres, L. (2009), Reshaping Public Sector Accounting: An International Comparative View, Canadian Journal of Administrative Sciences, Vol. 20, No. 4, pp. 334-350.

47. Pina, V., Torres, L., Yetano, A. (2009), Accrual Accounting in EU Local Governments: One Method, Several Approaches, European Accounting Review, Vol. 18, No. 4, pp. 765-804.

48. Poister, T.H. (2003), Measuring Performance in Public and Non-Profit Organizations, San Francisco.

49. Pollitt, C. (2013), The Logics of Performance Management, Evaluation, Vol. 19, No. 4, pp. 346-363.

50. Rodgers, R., Hunter, J.E. (1992), A Foundation of Good Management Practice in Government: Management by Objectives, Public Administration Review, Vol. 52, pp. 27-39.

51. Steger, G. (2010), Austria's Budget Reform: How to Create Consensus for a Decisive Change of Fiscal Rules, OECD Journal on Budgeting, Vol. 1, pp. 7-20.

52. Tickell, G. (2010), Cash to Accrual Accounting: One Nation's Dilemma, International Business and Economics Research Journal, Vol. 9, No. 11, pp. 71-78.

53. Van Helden, J., Johnsen, Å., Vakkuri, J. (2008), Distinctive Research Patterns on Public Sector Performance Measurement of Public Administration and Accounting Disciplines, Public Management Review, Vol. 10, No. 5, pp. 641-651.

54. Van Ryzin, G.G., Muzzio, D., Immerwahr, S. (2004), Explaining the Race Gap in Satisfaction with Urban Services, Urban Affairs Review, Vol. 39, No. 5, pp. 613-632.

55. Yamamoto, L. (2004), Automated Negotiation for On-Demand Inter-Domain Performance Monitoring, Proceedings of 2nd International Workshop on Inter-Domain Performance and Simulation, Budapest, Hungary, pp. 159-169.

56. European Commission (2013), Public Consultation Paper: Document Accompanying the Public Consultation "Towards Implementing European Public Sector Accounting Standards (EPSAS) for EU Member States Public Consultation on Future EPSAS Governance Principles and Structures", http://ec.europa.eu/eurostat/ documents/10186/752716/EPSASG_consultation_paper.pdf.

57. European Commission (2015), Progress Report on the Member States' Implementation of Council Directive 2011/85/EU, Article 3(2) Related to Fiscal Data, http://www.scb.se/Statistik/NR/NR0111/_dokument/MemberStates-implementation-of-Directive-2011-85-EU.pdf.

58. FEE (2007), Accrual Accounting in the Public Sector, Paper from the FEE Public Sector Committee.

59. IFAC (2014), IPSASB Public Sector Conceptual Framework, New York, http://www.ifac.org/public-sector/projects/ public-sector-conceptual-framework.

60. IPSASB (2014), Process for Considering GFS Reporting Guidelines during Development of IPSASs, https://www. ifac.org/system/files/publications/files/IPSASB-GFS-Policy-Paper.pdf.

61. IPSASB (2015), Recommended Practice Guideline 3: Reporting Service Performance Information, https://www. ifac.org/publications-resources/recommended-practice-guideline-3.

62. PwC (2014), Collection of Information Related to the Potential Impact, Including Costs, of Implementing Accrual Accounting in the Public Sector and Technical Analysis of the Suitability of Individual IPSAS Standards, http:// www.pwc.be/en/publications/2014/eurostat.jhtml.

63. https://www.ipsasb.org 